\title{
ASHURA RITUAL IN FADEL ILAHI ELDIMISKY'S NOVEL MUARA CINTA
}

\author{
Asnani \\ Universitas Islam Sumatera Utara, Medan, Indonesia \\ asnani@sastra.uisu.ac.id
}

Received: 01/07/2021

Accepted: 25/07/2021

Publication: 01/08/2021

\begin{abstract}
The purpose of the research is to elaborate on the Ashura Ritual in Karbala, Irak. The primer data are quotations taken from Fadel Ilahi Eldimisky's novel Muara Cinta. The research is qualitative research related to social problems. Damono in Wiyatmi (2008) states that sociology is an approach in literary studies that understands and evaluates literary works by considering social aspects. In the Indonesian Dictionary, rituals are defined as matters relating to procedures in religious ceremonies. Ashura ritual is done every ten of Muharram, the month of the Hijri lunar calendar. It is celebrated all over the world. In Karbala, Irak, the ritual has been performed by Shiah. The Ashura rituals found in Karbala are the ritual of beating the chest, hitting the back with a chain, and hurting the head and body. All the findings are analyzed in the discussion.
\end{abstract}

Keywords-Ashura, ritual, muara cinta, karbala

\section{Introduction}

The month of Muharram is the first month in the Hijri lunar calendar. It is a month that is believed to have many virtues. Therefore several practices are recommended to be carried out in this month. One of them is the practice of fasting Ashura, which is carried out on the 10th of Muharram, the reward of which can erase sins a year ago (Al-Hadith).

Ashura in Arabic means ten which refers to Muharram 10th. Ashura memorial rituals are performed all over the world. For example, in India, Ashura is carried out in open buildings or notable buildings called imambara or asyurkhanah by Sunnis and even Hindus. The term Ashura is seen as takziyah but is not implemented in a dramatic theatrical form. The celebration of Ashura in Egypt is not only celebrated by Muslims but also by Christians. In that country, they will share dessert. Thus, the celebration of the day of Ashura celebrated in Egypt has shifted its meaning to a social celebration.

The celebration of the Ashura ritual in Malaysia is done by making Ashura porridge together. Usually, the children also gather and wait for the porridge to be cooked. In its presentation, Asyura Malaysia porridge is unique. The porridge will be served in a bowl made from coconut shells and coated with banana leaves. In addition, the spoon used is no less unique. Usually, the spoon that will be used to eat Ashura porridge is made from pineapple leaves.

In addition to voluntary fasting, Indonesian people also have a unique tradition of celebrating Ashura Day. This tradition is commonly known as Eid for orphans. People who are well off will donate to orphans in the surrounding environment. Some of them specially organize events and invite orphans to the event. 
On the 10th of Muharram, a historical tragedy happened to the Prophet's grandson, Husain, and his family. He died on the 10th of Muharram in Karbala due to the injustice of Yazid bin Muawiyyah. The moments of Husain's martyrdom became the most dramatic and the most terrible moments. He slaughtered mercilessly sadistically. Whereas previously, Husain had suffered 45 wounds from swords and spears from the enemy and 35 arrows stuck in his body. Husain's left hand was cut and slashed in a cold and brutal manner, while spears pierced his chest. Then Shimir grabbed Husayn's hair, put a sharp sword around his neck. He rocked at Husain slowly until his neck broke. Then the items attached to Husain's body were looted. At the same time, his head was plugged into the spearhead and paraded in groups accompanied by dances and drums of war victory in the style of ancient Arab traditions (Heriyanto and Rukmana, ed.: 2013).

The ritual of the tragedy of the death of Husain is enshrined every year in Karbala, Iraq, by Shiah known as the Ashura ritual, Karbala ritual, or al-Husainiyyah ritual. Eldimisky sets the backdrop for this bloody ritual. This article is entitled the Ashura Ritual in Fadel Ilahi Eldimisky's Novel Muara Cinta.

\section{Literature Review}

In the Indonesian Dictionary, rituals are defined as matters relating to procedures in religious ceremonies. Van Gennep in Koentjaraningrat (1987) views rituals as activities to regenerate the spirit of social life among citizens. In the stages of growth as individuals, humans experience biological changes, and their social environment can affect the soul and cause mental crises. To deal with these changes, humans need the regeneration of the spirit of life. This is because there are always times when the spirit of social life is sluggish. At that point, the ritual is carried out to regenerate the spirit of life.

According to Ali and Muhdhor in Pasi (2018), ritual in the Arabic language is Sya'air. The word sya'air also means the practices and places of worship in the pilgrimage, such as wukuf, tawaf, sa'i, slaughtering sacrificial animals, and others. Abadi in Pasi (2018) adds that Sya'air also means anything stipulated by the Shari'a and ordered to be carried out. Smith in Handayani and Swazey (2018) states that a ritual often changes. He found that rituals are carried out in many religions in a fixed form of activity, but the background, beliefs, intentions, or doctrines may have changed. He added that rituals also have a social function, namely to streamline community solidarity. In a ritual, not everyone who takes part in it does it seriously as an obligation, but not a few do it carelessly. Their motivation in rituals is not merely to show devotion to God or find religious satisfaction but to consider rituals only as social obligations.

Bashori (2014) stated that the Shiah always carries out the Ashura commemoration every year. In the ritual, they wore black clothes on that day, accepted each other's ta'ziyah (condolences) for the killing of Husayn with sobs and lamentations, tore and tugged at their clothes slapped their cheeks (Shia). They took to the streets in a parade called Manakib Husainiyah, while they believed the procession to draw closer to Allah. According to Sheikh Al Bahrani in Pasi (2018), implementing the Ashura ritual must fulfill the following pillars. First, every ritual must contain and display an atmosphere of sadness and sorrow for calamities. Second, he must have the spirit and sincerity in carrying out these rituals, such as the spirit and sincerity of Husein in fighting for his goals and opinions. Third, the implementation of these rituals must contain the goals and values that Husein strives for. Without the three pillars above, the Ashura ritual does not achieve the value of its true purpose.

Al-Syīrāzi in Pasi (2018) added that one of the rituals that are often carried out on the commemoration of Ashura is hitting the face and chest. The Shiah will gather in a place that they consider holy on the 10th day of Muharram and then beat their chests, commonly called Maukib al-Lathm. The ritual is accompanied by a poetry reading by one person on the pulpit. 
Then, the people who beat earlier will answer several verses of the poem. Al-Haidarī in Pasi (2018) states that hitting with al-Salāsil (chain) or al Zanjiil. This is another self-torture ritual that is also often carried out by the Shiites in commemorating the death of Husein every Ashura day. Haidari also added that there is also a ritual of wounding the head and body carried out by a group of people who carry a sword in their hands called al-Qamat, which is a double-edged sword like the Romans' sword, but not too long. Unlike the previous ritual practitioners who wore black clothes, they wore all white clothes like a shroud. Then they will beat the knife or sword they carry on their heads until their blood runs down the white cloth they are wearing.

Ali-Fauzi (2009) states that there are three significant rituals in the Ashura commemoration series in Karbala. First, the rowzeh khavani ritual, a dramatic narrative reading of the life and suffering of the priests, especially Husein. First, there is rowzeh khavani, a dramatic narrative reading of the life and suffering of the priests, especially Husein. Second, the sinehzani event is a ritual of self-harm and lamentation which men generally carry out. This ritual contains a funeral procession; they are dressed in black, walking together in the form of a parade through the streets or markets on the tenth day of Muharram. Third, the story of Karbala is played in the form of drama, as a theatrical representation of the event, in what is called ta ziyeh. It is one of the oldest forms of theatrical performance in the Middle East, attended by ordinary people with great enthusiasm. The story of Husein's suffering, as well as his loyal followers, including women and children who suffered greatly, is played in this show.

\section{Research Method}

This research is qualitative research that studies the novel Muara Cinta by Fadel Ilahi Eldimisky. The instrument used in this research is the sociology of literary theory, which focuses on the sociological analysis, namely the things implied in the literary work itself related to social problems. Sociology of literature is a theoretical foundation that analyzes problems concerning the relationship between literature and society. Damono in Wiyatmi (2008) states that sociology is an approach in literary studies that understands and evaluates literary works by considering social aspects. The Karbala ritual is a social issue raised by the author, Fadel Ilahi Eldimisky, in his novel Muara Cinta.

\section{Results and Discussion}

In the novel Muara Cinta by Fadel Ilahi Eldimisky, the ashura ritual begins on the 1st of Muharram, held at the Sayyidah Zaenab Mosque in Syria. The area of this mosque is about twice the size of a football field. The mosque's main door is on the north side, which is decorated with calligraphy and reliefs. The dome is a shimmering golden yellow. The two tall towers that accompany it look like alabaster-blue marble. Inside the mosque, there are many crystal chandeliers, and the walls are made of porcelain and soft rugs. Just below the dome is the grave of Zaenab, the grandson of the Prophet Muhammad.

The Ashura ritual is performed once a year in the month of Muharram. This ritual is witnessed and followed by locals and from other countries of the world. Some follow this Ashura Ritual, and some are just as a witness of the ritual. But it is not easy to penetrate the pilgrims piled up like ants on a sugar tray. From the ring road of the mosque, pilgrims melt out for up to half a kilometer on the main road to and from Damascus. They came in groups from Damascus and other cities throughout Syria, mingling with Saudi Arabia, Kuwait, Iraq, Lebanon, Afghanistan, and Iran.

The purpose of the pilgrims was not to participate in Ashura rituals because not all of them were Shia. Some-especially domestic pilgrims around Damascus-just want to go on an excursion, see firsthand the gruesome theater, and spread the rancid smell of blood, like 
enjoying an eccentric and strange panorama. (Eldimisky, 2019:4) There are three forms of Ashura Ritual contained in the novel Muara Cinta by Fadel Ilahi Eldimisky.

\section{Ritual of Beating the Chest}

From the 1st to the 9th of Muharram, the Shia gathered in the Sayyidah Zaenab mosque. They sat in groups filling the large courtyard of the mosque. In the novel Muara Cinta, Eldimisky explains the atmosphere in the courtyard of the Sayyidah Zaenab mosque, which is filled with Shiites who carry out the Ashura ritual procession.

I observed one group after another that filled the courtyard in the mosque, which was wide and open without a roof. From large groups consisting of hundreds of people to small groups of less than 20 people. (Eldimisky, 2019:2)

In performing the Ashura ritual, the Shia in the mosque sit in small groups of 20 people, and some are in large groups of hundreds of people. They sat cross-legged in a lined formation, chanting sad remembrance while beating their chests. Their right-hand beats the chest on the left. The right chest was beaten by the left hand. The beats accompanied the rhythmic remembrance, just like the beat of a drum in pop music. Visible and dominant. (Eldimisky, 2019:2)

The ritual from the 1st to the 9th of Muharram that the Shia performs is beating the chest while sitting in groups in the Zaenab mosque. They sat cross-legged and formed a lined formation. The ritual of hitting the chest is done while making sad remembrance. The sadness they felt was likened to sadness because of the torture experienced by Imam Husayn.

The ritual of hitting the chest is carried out utilizing the left hand hitting the right chest, while the right-hand hits the left chest rhythmically with the sad remembrance. The blow to the chest is likened to the author as 'like the beat of a drum in pop music, which makes an echoing, rhythmic sound and dominates the Sayyidah Zaenab mosque.

Fahmi as the protagonist in the novel Muara Cinta is very interested in the Ashura ritual. He spent the first 9 days of Muharram witnessing the ritual of Ashura back and forth from Damascus to Karbala. To attend the peak of Ashura on 10 Muharram, Fadel spent the night at the house of his friend, Firman, a fellow Indonesian, whose house is closest to the Sayyidah Zaenab mosque.

Ya. For nine days, every day, I was among them observing one group after another that filled the large, open-air courtyard of the mosque, from large groups consisting of hundreds of people to small groups consisting of less than 20 people. Once satisfied, I left the mosque and returned to Damascus. That's it, for nine days! ((Eldimisky, 2019:2)

\section{The Ritual of Hitting the Back with A Chain}

The ritual form of hitting the back with a chain is carried out by several people sitting in groups in the front row.

There are one or two people sitting in the front row in each group, holding a half-size chain. The two ends of the chain were struck behind the back, repeatedly, as if to invite pain like that suffered by the heroes who inspired this Ashura ritual. Even if, of course, their pain was nothing compared to the pain that befell the heroes of the Karbala War. (Eldimisky, 2019:2)

The chain used as a tool to injure the back of the back is made of iron. This is done repeatedly rhythmically. They deliberately hit themselves on the back in the hope of feeling Imam Husayn's suffering when the Ashura incident occurred.

\section{Rituals of Hurting the Head and Body}

Ashura commemoration on the 10th of Muharram begins in the morning after the Fajr prayer; the sky is still dark. Thousands of people walk around the Sayyidah Zaenab mosque.

Last year, I managed to circle the Sayyidah Zaenab Mosque at the same celebration for seven rounds. In the first round, my feet were like being beaten by a security guard's club. The second round was even worse. And so on. It was like being forced to climb a hill full of inclines without first warming up. (Eldimisky, 2019: 5) 
The ritual of walking around the Sayyidah Zaenab Mosque for seven rounds is done like Tawaf during Hajj. They consider that the Ashura ritual is a practice like the practice of Hajj. Because of the size of the Sayyidah Zaenab mosque, the ritual of walking around this mosque was felt to be very tiring. This was done as an embodiment and warning of the suffering of Sayyidah Zaenab who was forced to walk with her arms and legs in chains, hundreds of miles from Karbala to Damascus.

It is said-I don't know for sure-he was forced to walk hundreds of miles from Karbala in Iraq to Damascus. Imagine if I was tired of going around the mosque complex once; what about Zaenab? (Eldimisky, 2019:6)

On the 10th of Muharram, after the Fajr prayer, the peak of the Ashura ritual took place. Thousands of people, especially men, who were wearing white robes but mostly black robes, started the ritual by going out into the street, surrounding the Sayyidah Zaenab mosque.

After the Fajr prayer on a wet morning, the ceremony culminated. Thousands of people are now pouring into the streets, wearing black robes. Only a tiny number wore white robes and held sharp, shiny swords. They pushed slowly around the circular path, like striped snakes coiling around a large mosque building. Their mouths chant one name, over and over again and rhythmically, "Haidar! Heydar! Heydar!" (Eldimisky, 2019:1)

The word 'Haidar,' which is echoed, refers to Ali bin Abi Talib, the father of Imam Husayn, who died in Karbala. The shouts calling Haidar's name became their passion for hurting themselves by using a long sword. They felt that the pain they felt was not comparable to the pain felt by the war heroes of Karbala.

People wearing white robes brandished their swords in the air. Suddenly, they pointed their swords at their heads and struck them several times as if on command. His friend slashed the one who did not carry a sword. Then, their left hand patted the injured head. Drops of red blood splashed onto the top of the robes they were wearing. Their white faces were covered in blood. A rancid smell wafted into the air, which grew brighter and brighter. (Eldimisky, 2019:1)

From the quote above, it is known that those who carry out the stabbing are those who wear white robes. They brandished their swords high in the air and then slashed themselves in the head. Then the left hand patted the injured head so that blood was splashed everywhere. They also slashed his friend, who was wearing a white robe but not carrying a sword.

I walk relatively fast. In front of me, several young people of ecstasy were chanting Haidar's name. Blood melted on their foreheads. The longer it goes on, the clapping on their heads gets louder. Someone stopped suddenly. The long curved sword that he had been brandishing earlier was now aimed at his head. Then he bravely slashed the sword into the open wound several times. Fresh blood flowed profusely. His face was pale. His eyes were twinkling like tears of blood. (Eldimisky, 2019:3)

The quote above illustrates that youths carry out the Karbala ritual. The youths seemed to be in a state of unconsciousness, hurting themselves by pointing a long sword at his head, slashing their head repeatedly so that blood flowed profusely.

The young man's body was thin but looked haughty with a sword that gleamed in the light bulb. Judging from his two slanted mongoloid eyes and sharp eyebrows, although not thick, I can confirm that the young man is from Afghanistan. I estimate he is fifteen years old. Impulsive age. (Eldimisky, 2019:3)

The ritual of hurting the head begins with brandishing a sword in the air while shouting Haidar's name, Ali bin Abi Talib, Imam Husayn's father. They circled the Saiyydah Zaenab mosque for seven rounds, then started slashing themselves in the head.

After bleeding quite a lot, the 15-year-old boy finally staggered and was carried away by his friends. Finally, the young man was rushed to the hospital. Fahmi took care of the 15year-old young man until he took him to the hospital, donated his blood, and signed a guardian's letter for a permit for surgery, but his life could not be saved.

Like the pillars of the Ashura ritual, each ritual must display an atmosphere of sadness. Sad remembrance that was said with tears in my eyes. At the same time, the ritual of hitting the chest with enthusiasm is the second pillar of the Ashura ritual, which is severe and passionate in 
its implementation. The third pillar is that implementing the ritual must contain the goals and values that Imam Husain fought for. The values that Imam Husayn championed were justice. They commemorate the death of Imam Husayn because of the injustice that occurred at that time.

\section{Conclusion}

After analyzing Ashura Ritual, the writer concludes that three Ashura rituals are performed in Karbala, Irak. They are rituals of beating the chest, the ritual of hitting the back with a chain, and the ritual of hurting the head and body. All the rituals have happened every Muharram, 10th.

\section{References}

Akbar, Rofiq Faudy. (2015). Analisis Persepsi Pelajar Tingkat Menengah pada Sekolah Tinggi Agama Islam Negeri Kudus. Jurnal Edukasia. Jurnal Penelitian Pendidikan Islam. Vol 10. No. 1 (2015)

Bashori, Agus Hasan. (2014). "Asyura membuka kedok Syi'ah". Retrieved from http://www.gensyiah.com. Accessed on 27 Pebruary 2021.

Dadan Suwarna dan Aquarini Priyatna. (2014). Tragedi dalam Lima Cerpen Karya Martin Aleida (Tragedy in Martin Aleida's Five Short Stories). Jurnal Penelitian Sastra: Metasastra. ISSN 2085-7268. Vol.7 No.1 Juni 2014.

Eldimisky, Fadel Ilahi. (2019). Muara Cinta. Surabaya: Gramedia Pustaka Utama.

Harbani, Rahma Indina. (2021). 4 Keutamaan Bulan Muharram yang Perlu Diketahui Umat Islam" retrieved from https://news.detik.com/berita/d-5679233/4-keutamaan-bulanmuharram-yang-perlu-diketahui-umat-islam.

Heriyanto, Husain dan Rukmana, Aan. (2013). Hikmah abadi revolusi imam Husain. Jakarta: Sadra Press.

Hornby, A.S. (2010). Oxford Advanced Learner's Dictionary of Current English. New York: Oxford University Press.

Koentjaraningrat. (1987). Sejarah Teori Antropologi. Jakarta: UI Press.

Pasi, Kamaluddin MH. (2018). Kontroversi Penyiksaan Diri dalam Ritual 'Asyūrā Menurut Pandangan Syiah. Retrieved from https://dppai.uii.ac.id > web > uploads > 2018/12 accessed on 1 October 2021

Syarbini, Amirulloh dan Afgandi, Lis Nur'aeni. (2010). Dahsyatnya Puasa Sunah: Kunci Utama Merah Sukses Dunia dan Akhirat. Jakarta: Kawan Pustaka.

Wiyatmi. (2008). Pengantar Kajian Sastra. Yoyakarta: Pustaka Pelajar 